\title{
FUZZY CONTROLLED COMBINED CUK-SEPIC HYBRID DC-DC CONVERTER FOR STANDALONE APPLICATIONS
}

\author{
Varun Jo Abu ${ }^{1}$, Sija Gopinathan ${ }^{2}$, Ninu Joy ${ }^{3}$ \\ ${ }^{I}$ PG Scholar, Electrical and Electronics Department, Mar Athanasius College of Engineering, Kerala, India \\ ${ }^{2}$ Assistant Professor, Electrical and Electronics Department, Mar Athanasius College of Engineering, Kerala, India \\ ${ }^{3}$ Assistant Professor, Electrical and Electronics Department, Mar Athanasius College of Engineering, Kerala, India
}

\begin{abstract}
The difference between the energy demand and the available energy is increasing every year due to the limitation in the conventional energy resources in the earth. This extra demand can be easily covered by the efficient utilization of the abundant renewable energy resources around us. Energy from these sources can be utilised in rural electrification, domestic standalone systems, etc. The main challenge related with the renewable energy sources is their fluctuating nature, i.e., it is incapable of maintaining a constant output. Hybridization technique is utilized to overcome this problem. Here, a multi-input DC-DC converter is proposed which is capable of supplying a constant output voltage. A solar array and a fuel cell can be connected as the inputs to the converter. When compared with the conventional multi-input converters, the proposed circuit has a lower active and passive component count. The sources can meet the load individually or simultaneously depending on their availability. So, the converter is able to provide the required constant output voltage taking power from both/either of the sources. The converter is a combination of the basic Cuk and SEPIC converters. The output side inductor and capacitor of the basic Cuk and SEPIC converters are integrated into a single inductor and capacitor to realize this multi input converter. Solar array output is connected to the input port of the Cuk converter section and the fuel cell is connected as the input to the SEPIC converter section. The control of the converter is established using Fuzzy Logic Control. Experimental results are observed to check the performance of the converter. The microcontroller used in the setup is dsPIC30F2010. In the experimental setup, a servo motor has been connected as the load, through a two leg inverter.
\end{abstract}

Keywords: Hybrid system, Cuk-SEPIC converter, PV system, Fuel cell, Fuzzy logic control, Servo motor

\section{INTRODUCTION}

Rise in the energy demand and limitation in fossil fuels have increased the role of renewable energy resources. Systems based on petroleum product and fossil fuels will result in environmental pollution and hence global warming. This elevated the need for renewable energy sources which is abundant and environment friendly. Renewable sources like solar wind energy are capable of supplying energy to meet the power demand. Even though the capital cost and space requirement for such systems are high, the running cost is extremely low. Their applications can be easily utilized in distributed generation, micro grid, etc. The main disadvantage of such a system is its unpredictable and intermittent nature, i.e., the output from these systems will always be fluctuating. To overcome this challenge, hybrid renewable energy systems were implemented which clubs two or more energy resources to produce a constant output. Fuel cells and batteries can also be used as inputs to maintain the output. Hybridization improves the efficiency and life of the system and also brings down the storage requirement. At the same time, the capital cost and complexity can increase as a result of hybridization.

Conventional topologies employ multiple single input converters, i.e., one converter for each input and only the load section is common for the converters. But in renewable energy systems, multiple input converters (MIC) are more advantageous than the conventional converters. They have a simpler structure, improved power density and more economic characteristic because of sharing active switches and other components. Thus MIC is a more suitable for renewable power systems and has good development prospects. Conventional hybrid systems [1-4] use individual DC-DC boost converter for each input source and later they are connected in parallel as in a block diagram shown in figure 1. Other conventional converters include simpler multi-input structures that combine the sources from the DC-end and achieving maximum power point tracking (MPPT) for each source [5] and combination structures of basic buck/boost/buck-boost converters. These require passive input filters to eliminate the high frequency current harmonics injected into wind turbine generators. The harmonic content in the generator current brings reduces the life and increases the power loss due to heating. The conventional converters which include parallel DC-DC converters need a supervisory control for the switching of sources.

An alternative multi-input rectifier topology is developed here. The design presented is a combination of the conventional Cuk and SEPIC converters. The features of the topology are: 1) each input can be stepped up or stepped down according to the requirement; 2) If required, maximum power point tracking can be realized for each 
sources; 3) Both individual and simultaneous operation is possible.

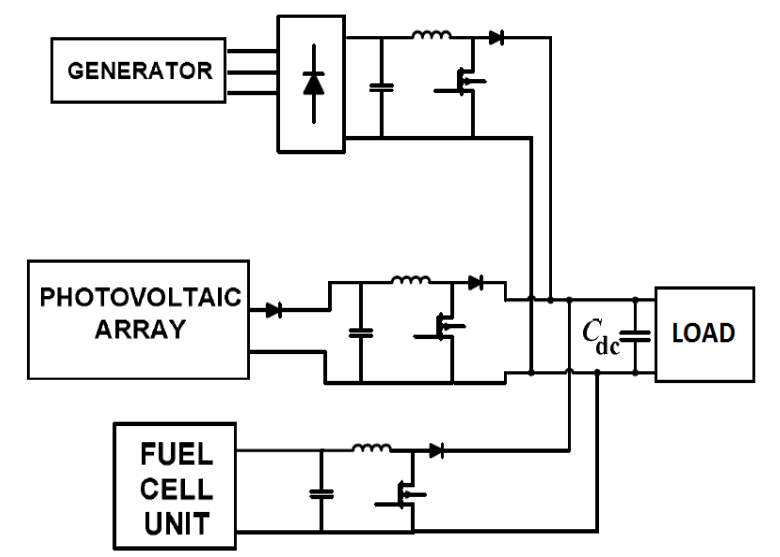

Fig -1: Hybrid system with multi-connected boost converters

\section{COMBINED CUK-SEPIC FUSED MULTI-}

\section{INPUT CONVERTER}

In this paper, a solar array - fuel cell hybrid DC-DC converter is presented. By combining these two inconsistent power sources, a constant output voltage can be obtained, ensuring the continuity and reliability of the supply. Also, the power transfer efficiency of the system is improved. The hybrid converter presented can have simultaneous or individual operation. During daytime, sunlight is abundantly available. A PV panel can convert this solar power to electrical power and it is connected to the first input port of the converter. A fuel cell is connected to the second input port. Inside a fuel cell, chemical energy is converted to electrical energy. It can operate at a much higher efficiency than an IC engine with the same amount of fuel. The main inputs to a fuel cell are hydrogen and oxygen. Oxygen is easily available from the atmosphere and hydrogen can be obtained from various means, e.g.: from methane produced from biogas. The fuel cell itself has no moving parts, providing a quiet and reliable power source.

The converter topology described here is a combination of the basic Cuk converter and SEPIC converter. The output sections of these individual converters have been integrated into a single section to develop the topology. Hence, the number of passive components has been reduced in the circuit. The inherent nature of these Cuk and SEPIC converters rules out the need for separate input filters. Moreover, it is possible to step up/step down both the input voltages individually. The circuit diagram of the hybrid fuel cell-solar energy system is shown in figure 2 . The combination of the two converters is achieved by reconfiguring the two existing diode from both converters and by sharing of the Cuk output inductor by the SEPIC converter. $V_{1}$ is taken as the solar array input and $V_{2}$ as the fuel cell input. $M_{1}$ and $M_{2}$ are the switches in the Cuk section and SEPIC section of the circuit respectively. $L_{1}$ and $\mathrm{C}_{1}$ are the input inductor and coupling capacitor of the Cuk converter section. Similarly, $\mathrm{L}_{3}$ and $\mathrm{C}_{3}$ are the input inductor and coupling capacitor of the SEPIC converter section. Diodes $\mathrm{D}_{1}$ and $\mathrm{D}_{2}$ of the converters are reconfigured in this circuit. $\mathrm{L}_{2}$ and $\mathrm{C}_{2}$ are the output inductor and output capacitor of the converter. $\mathrm{R}$ is the load resistor and a constant voltage is obtained across it.

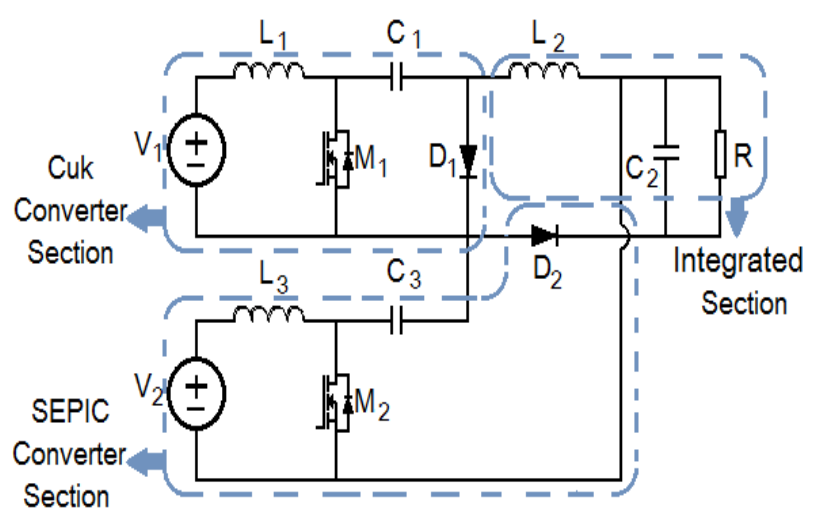

Fig -2: Circuit diagram of the combined Cuk-SEPIC converter

\subsection{Modes of Operation}

Depending on the state of the switches $\mathrm{M}_{1}$ and $\mathrm{M}_{2}$, there are four modes of operation.

\subsubsection{Mode $1\left(\mathrm{M}_{1} \mathrm{ON}, \mathrm{M}_{2} \mathrm{ON}\right)$}

Both switches $\mathrm{M}_{1}$ and $\mathrm{M}_{2}$ are turned $\mathrm{ON}$ during this mode. Inductors $L_{1}$ and $L_{3}$ are charged. Also, diodes $D_{1}$ and $D_{2}$ are reverse biased. None of the input current reaches the load section. During this time, the load will be powered by the charge stored in the output capacitor. The equivalent circuit diagram during this mode is shown in figure 3 .

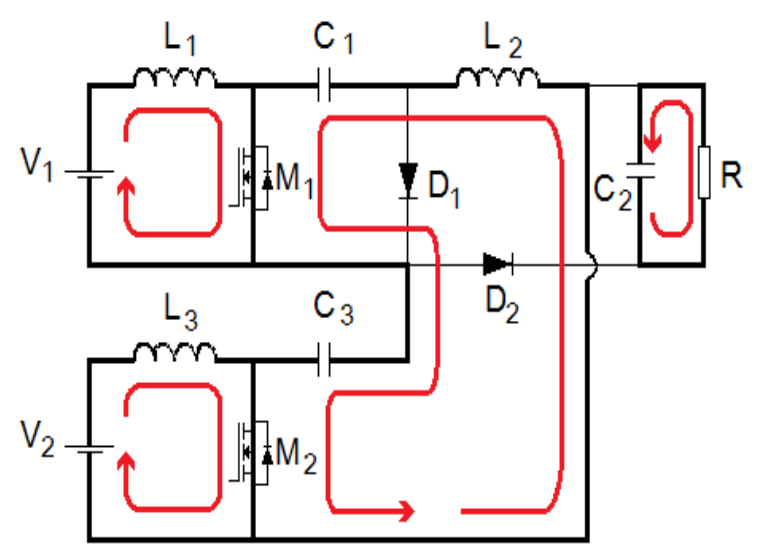

Fig -3: Mode 1: Equivalent circuit

\subsubsection{Mode $2\left(\mathrm{M}_{1} \mathrm{ON}, \mathrm{M}_{2} \mathrm{OFF}\right)$}

Switch $\mathrm{M}_{1}$ is $\mathrm{ON}$ and switch $\mathrm{M}_{2}$ is OFF during this mode. Inductor $\mathrm{L}_{1}$ gets charged during this mode. Inductor current $\mathrm{i}_{\mathrm{L} 3}$ forward biases the diode $\mathrm{D}_{2}$. Diode $\mathrm{D}_{1}$ is reverse biased. Now current $i_{L 3}$ reaches the load section of the converter and charges the output capacitor along with the load. Figure 4 presents the equivalent circuit diagram during this mode. 


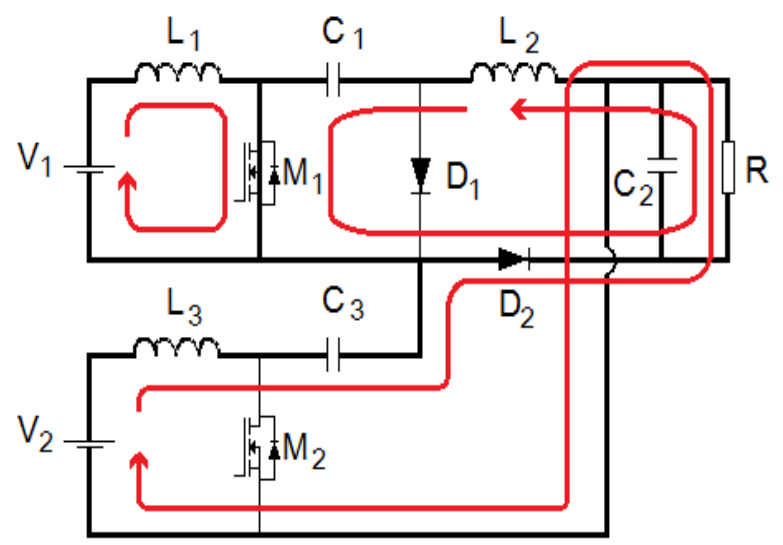

Fig -4: Mode 2: Equivalent circuit

\subsubsection{Mode $3\left(\mathrm{M}_{1}\right.$ OFF, $\left.\mathrm{M}_{2} \mathrm{ON}\right)$}

Switch $\mathrm{M}_{1}$ is OFF and switch $\mathrm{M}_{2}$ is turned $\mathrm{ON}$ in this mode. Inductor $\mathrm{L}_{3}$ gets charged. Inductor current $\mathrm{i}_{\mathrm{L} 1}$ forward biases the diode $\mathrm{D}_{1}$ and freewheels through it. Diode $\mathrm{D}_{2}$ is reverse biased. During this time, the load will be powered by the charge stored in the output capacitor. Figure 5 presents the equivalent circuit diagram during this mode.

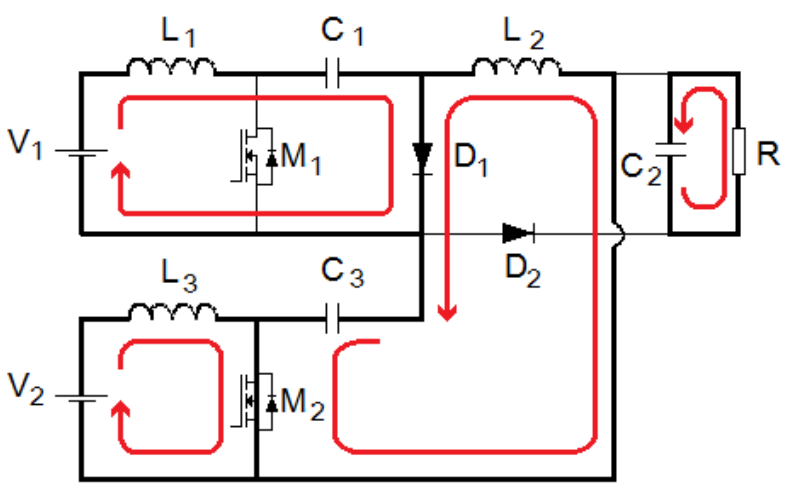

Fig -5: Mode 3: Equivalent circuit

\subsubsection{Mode $4\left(\mathrm{M}_{1}\right.$ OFF, $\mathrm{M}_{2}$ OFF $)$}

Both switches $M_{1}$ and $M_{2}$ are turned OFF during this mode. Inductor currents $i_{L 1}$ and $i_{L 3}$ forward biases diodes $D_{1}$ and $D_{2}$. Also the current $i_{L 3}$ reaches the output section. Along with it, the inductor $\mathrm{L}_{2}$ discharges during this mode though the output capacitor and load. The equivalent circuit diagram during this mode is shown in figure 6 .

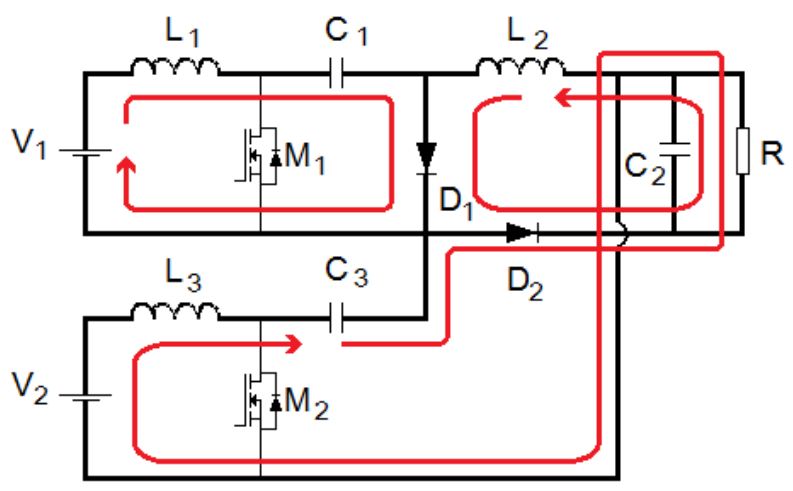

Fig -6: Mode 4: Equivalent circuit

\section{CONTROL OF THE CONVERTER}

The multi-input converter presented in this project need to deliver a constant DC output voltage to the load even if any of the input is absent. That is, continuity of the output should be ensured whatever be the input, in order to make the system reliable. To ensure this, fuzzy logic control has been established. Fuzzy logic control includes establishing a fuzzy inference system with the input and output membership functions and defining the rules related with it. Here, we have two input membership functions: 1) Error in output voltage - "error", and 2) Changing error "deltaerror". The only output membership function is the duty cycle - "output1". These membership functions are plotted in the following figures $7 \& 8$.

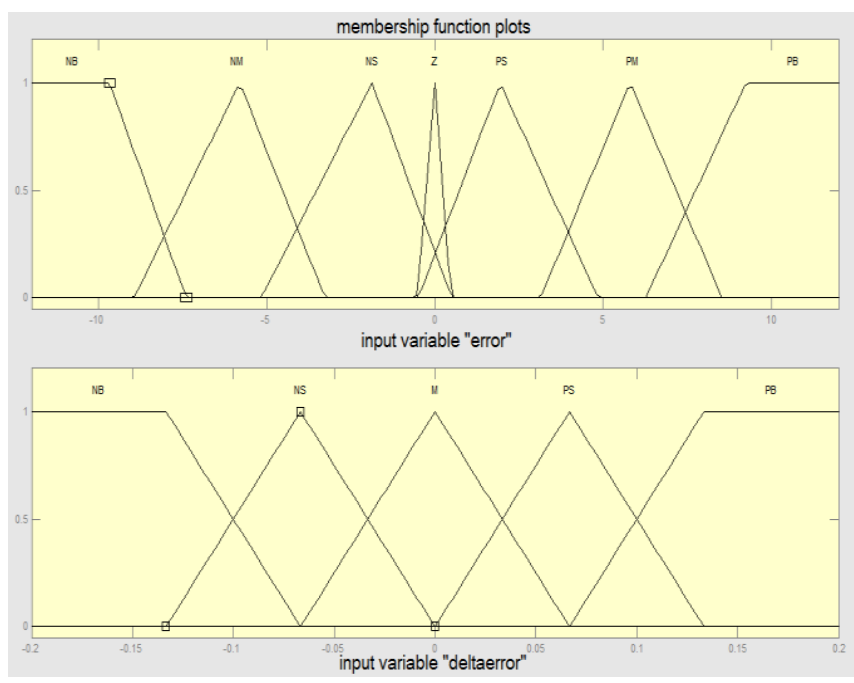

Fig -7: Input membership function plots

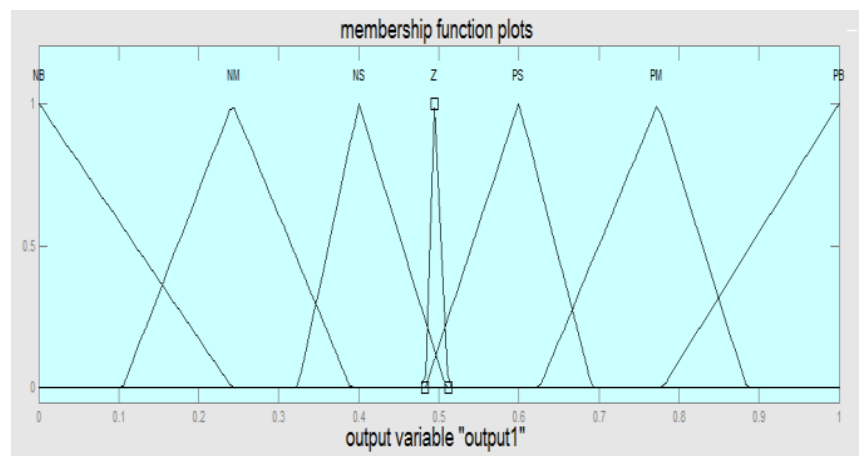

Fig -8: Output membership function plot

\subsection{Control Strategy: Simultaneous Operation}

During simultaneous operation of the converter, the power from both inputs is summed up to deliver power to the load. For this control strategy, pulses have to be given to both switches $\mathrm{M}_{1}$ and $\mathrm{M}_{2}$. The pulses to these switches are $180^{\circ}$ phase shifted. For enabling proper current sharing from the input sources, both pulses have the same duty cycles. If the pulses are in phase, both switches will be turned ON at the same instant during each switching cycle. This can result in longer duration of mode $1\left(\mathrm{M}_{1}, \mathrm{M}_{2} \mathrm{ON}\right)$. This means that the input current from none of the sources reaches the output section of the converter. As a result, the load gets charged 
from the output capacitor $\mathrm{C}_{2}$ continuously (see figure 3 ). The charge in $\mathrm{C}_{2}$ reduces and hence the output voltage starts reducing inducing ripples in the output voltage. For these reason, $0^{\circ}$ phase shifted pulses are not provided to the switches. If $180^{\circ}$ phase shifted are supplied, there is only a lesser chance of occurrence of mode 1 . So, either of the input current reach the output section of the converter most of the time. As a result, it can reduce the ripples in the output voltage waveform.

\subsection{Control Strategy: Individual Operation}

During individual operation, one of the input sources to the hybrid converter is unavailable and it has to continue its operation with the remaining input source. During this case, the power from the available input source must be able to satisfy the load power demand. When only the solar array input is available, the converter operates as an ordinary Cuk converter. During this operation, only the switch $\mathrm{M}_{1}$ operates. Its duty cycle adjusts automatically to deliver the required output voltage. When only the fuel cell input is available, the converter operates as a SEPIC converter. During this time, only switch $\mathrm{M}_{2}$ operates and its duty cycle adjusts to maintain the output voltage.

\section{ANALYSIS OF THE CIRCUIT}

$\mathrm{V}_{1}-\mathrm{PV}$ array voltage

$\mathrm{V}_{2}-$ Fuel cell voltage

$\mathrm{V}_{\mathrm{o}}$ - Output voltage

$\mathrm{d}_{1}$ - Duty cycle of switch $\mathrm{M}_{1}$

$\mathrm{d}_{2}$ - Duty cycle of switch $\mathrm{M}_{2}$

$\mathrm{F}_{\mathrm{s}}$ - Switching frequency

$\mathrm{T}_{\mathrm{s}}-$ Switching time

$\mathrm{P}_{\mathrm{o}}-$ Output power

The net change in inductor current across $\mathrm{L}_{1}$ is zero.

$$
\begin{gathered}
\left(\Delta i_{L 1}\right)_{\text {closed }}=\left(\frac{V_{1}}{L_{1}}\right) * d_{1} * T_{s} \\
\left(\Delta i_{L 1}\right)_{\text {open }}=\left(\frac{V_{1}}{L_{1}}\right) *\left(1-d_{1}\right) * T_{S} \\
\left(\Delta i_{L 1}\right)_{\text {closed }}+\left(\Delta i_{L 1}\right)_{\text {open }}=0 \\
V_{C 1}=\frac{V_{1}}{\left(1-d_{1}\right)}
\end{gathered}
$$

Similarly, the net change in inductor current across $\mathrm{L}_{3}$ is zero.

$$
\begin{gathered}
\left(\Delta i_{L 3}\right)_{\text {closed }}=\left(\frac{V_{2}}{L_{3}}\right) * d_{2} * T_{S} \\
\left(\Delta i_{L 1}\right)_{\text {open }}=\left(\frac{V_{2-V_{C 2}-V_{o}}}{L_{3}}\right) * d_{2} * T_{S} \\
\left(\Delta i_{L 3}\right)_{\text {closed }}+\left(\Delta i_{L 3}\right)_{\text {open }}=0 \\
V_{C 2}=\frac{V_{2}}{\left(1-d_{2}\right)}-V_{o}
\end{gathered}
$$

The average voltage across inductor L2 is zero.

$$
\begin{aligned}
& {\left[\left(V_{C 1}+V_{C 2}\right) * d_{1} * T_{s}\right]+\left[V_{C 2} *\left(d_{2}-d_{1}\right) * T_{s}\right]+} \\
& {\left[\left(1-d_{2}\right)\left(-V_{o}\right)\right]=0}
\end{aligned}
$$

Substituting the equations (4) and (8) in (9),

$$
V_{o}=\left(\frac{d_{1}}{1-d_{1}}\right) * V_{1}+\left(\frac{d_{2}}{1-d_{2}}\right) * V_{2}
$$

Equation (10) shows that the output DC voltage can be adjusted by controlling the duty cycles $d_{1}$ and $d_{2}$.

\section{DESIGN OF COMPONENTS}

The values of the inductors are given by,

$$
\begin{gathered}
L_{1}=V_{1} *\left(\frac{d_{1}}{\Delta i_{L 1} * F_{S}}\right) \\
L_{2}=\left(1-d_{1}\right) *\left(\frac{R}{2 * F_{S}}\right) \\
L_{3}=V_{2} *\left(\frac{d_{2}}{\Delta i_{L 3} * F_{S}}\right)
\end{gathered}
$$

The value of capacitors are obtained by,

$$
\begin{gathered}
C_{1}=\frac{d_{1}}{R * F_{s} *\left(\frac{\Delta V_{C 1}}{V_{o}}\right)} \\
C_{2}=\frac{1-d_{2}}{8 * L_{2} * F_{S}^{2} *\left(\frac{\Delta V_{C 2}}{V_{o}}\right)} \\
C_{3}=\frac{d_{2}}{R * F_{s} *\left(\frac{\Delta V_{C 3}}{V_{o}}\right)}
\end{gathered}
$$

Take $\mathrm{V}_{1}=10 \mathrm{~V}, \mathrm{~V}_{2}=14 \mathrm{~V}, \mathrm{~V}_{\mathrm{o}}=12 \mathrm{~V}, \mathrm{P}_{\mathrm{o}}=40 \mathrm{~W}$.

Load Resistance,

$$
\begin{gathered}
R=\frac{V_{o}^{2}}{P_{o}}=3.6 \Omega \\
I_{1}=I_{L 1}=\frac{P_{1}}{V_{1}}=4 A \\
V_{o}=\frac{d_{1}}{\left(1-d_{1}\right)} V_{1} \Rightarrow d_{1}=0.54
\end{gathered}
$$

Similarly,

$$
\begin{array}{r}
I_{2}=I_{L 3}=\frac{P_{2}}{V_{2}}=2.857 \mathrm{~A} \\
V_{o}=\frac{d_{2}}{\left(1-d_{2}\right)} V_{2} \Rightarrow d_{2}=0.46
\end{array}
$$

Substituting these values in equations (11)-(13), the value of inductors is obtained as $\mathrm{L}_{1}=220 \mu \mathrm{H}, \mathrm{L}_{2}=41 \mu \mathrm{H}$ and $\mathrm{L}_{3}=370$ $\mu \mathrm{H}$. 
Voltages across the capacitors are given by equations (4), (8) and (22).

$$
V_{C 3}=\frac{V_{2}}{\left(1-d_{2}\right)}
$$

Substituting the above obtained values, the capacitor voltages can be calculated as, $\mathrm{V}_{\mathrm{Cl}}=21.97 \mathrm{~V}, \mathrm{~V}_{\mathrm{C} 2}=14 \mathrm{~V}$, $\mathrm{V}_{\mathrm{C} 3}=26 \mathrm{~V}$.

Converting these capacitor voltage values in equations (14)(16), we get the value of capacitors as $\mathrm{C}_{1}=140 \mu \mathrm{F}, \mathrm{C}_{2}=120$ $\mu \mathrm{F}$ and $\mathrm{C}_{3}=100 \mu \mathrm{F}$.

\section{SIMULATION RESULTS}

The Cuk-SEPIC combined multi-input DC-DC converter is drawn and simulated in MATLAB R2014a/Simulink. Fuzzy logic control (FLC) is a more advanced and robust feedback control strategy. Table 1 lists the simulation parameters used.
Table -1: Simulation Parameters

\begin{tabular}{|c|c|c|}
\hline \multicolumn{2}{|c|}{ Parameters/Components } & Values \\
\hline \multicolumn{2}{|c|}{ Input Voltage $1\left(\mathrm{~V}_{1}\right)$} & $10 \mathrm{~V}$ \\
\hline \multicolumn{2}{|c|}{ Input Voltage $2\left(\mathrm{~V}_{2}\right)$} & $14 \mathrm{~V}$ \\
\hline \multicolumn{2}{|c|}{ Output Voltage $\left(\mathrm{V}_{\mathrm{o}}\right)$} & $12 \mathrm{~V}$ \\
\hline \multicolumn{2}{|c|}{ Power Output $\left(\mathrm{P}_{\mathrm{o}}\right)$} & $40 \mathrm{~W}$ \\
\hline \multirow{3}{*}{ Inductors } & $\mathrm{L}_{1}$ & $220 \mu \mathrm{H}$ \\
\hline & $\mathrm{L}_{2}$ & $41 \mu \mathrm{H}$ \\
\hline & $\mathrm{L}_{3}$ & $370 \mu \mathrm{H}$ \\
\hline \multirow{3}{*}{ Capacitors } & $\mathrm{C}_{1}$ & $140 \mu \mathrm{F}$ \\
\hline & $\mathrm{C}_{2}$ & $120 \mu \mathrm{F}$ \\
\hline & $\mathrm{C}_{3}$ & $100 \mu \mathrm{F}$ \\
\hline \multicolumn{2}{|c|}{ Switching Frequency $\left(\mathrm{F}_{\mathrm{s}}\right)$} & $20 \mathrm{kHz}$ \\
\hline \multicolumn{2}{|c|}{ Load Resistor (R) } & $3.6 \Omega$ \\
\hline
\end{tabular}

Figure 9 shows the model of the converter with fuzzy controlled feedback circuit.

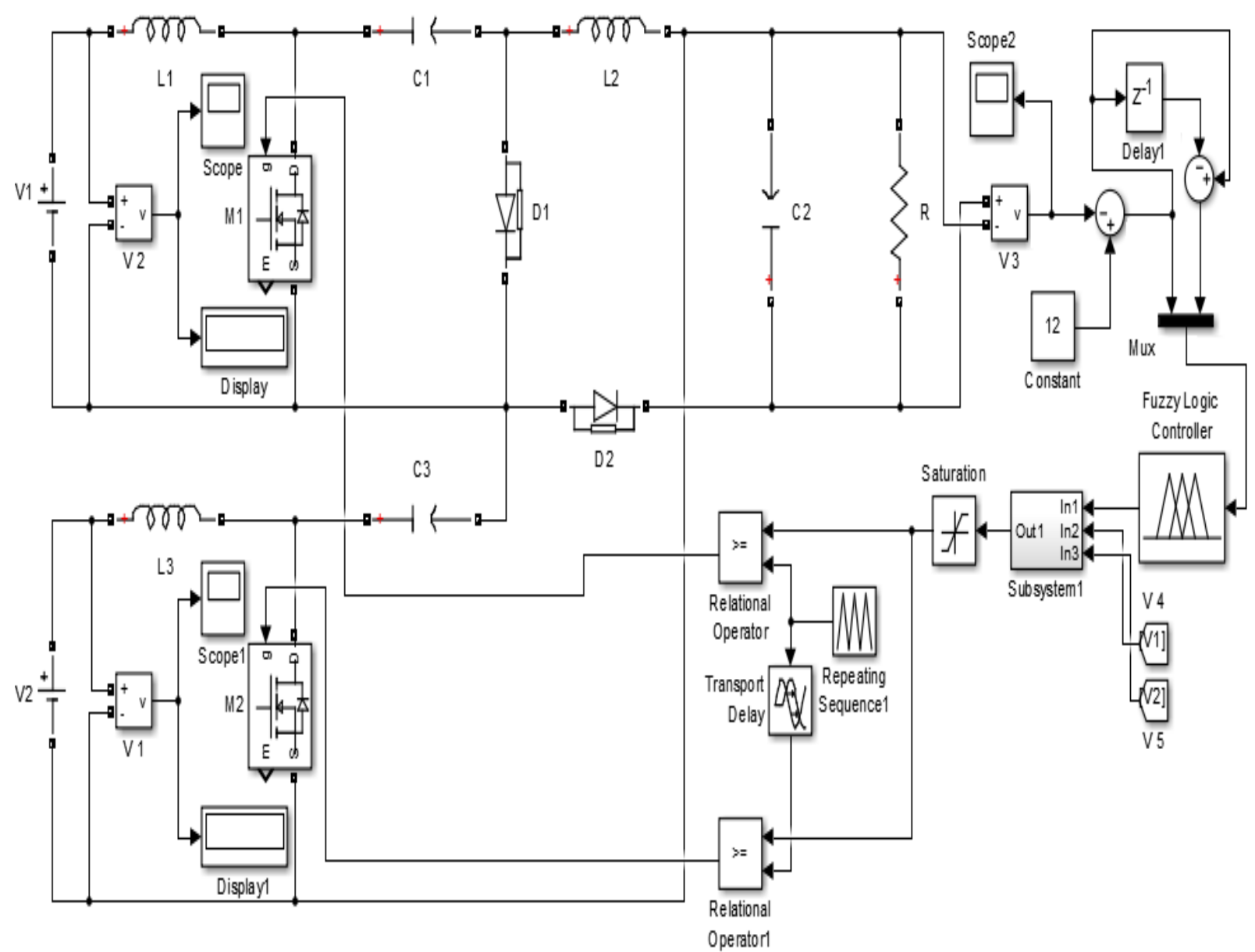

Fig -9: Simulink model of the converter with fuzzy control

\subsection{Simultaneous Operation}

Input terminal 1 and input terminal 2 is connected to $10 \mathrm{~V}$ DC and $14 \mathrm{~V}$ DC respectively during simultaneous operation. Figure 10 shows the input voltages and figure 11 shows the obtained output voltage and current. 


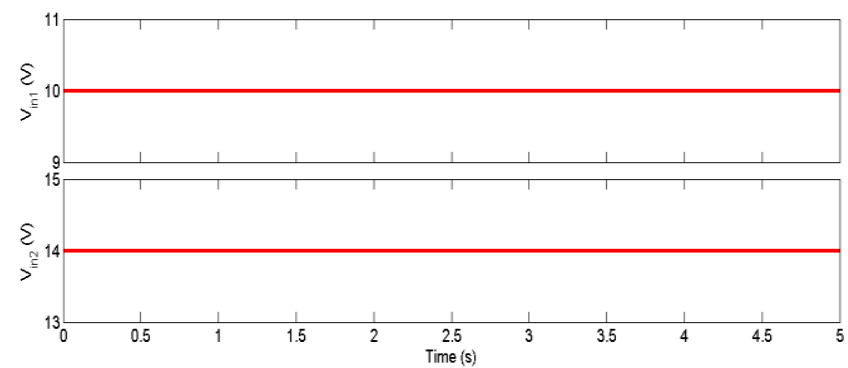

Fig -10: Simultaneous operation: Input voltage 1, Input voltage 2

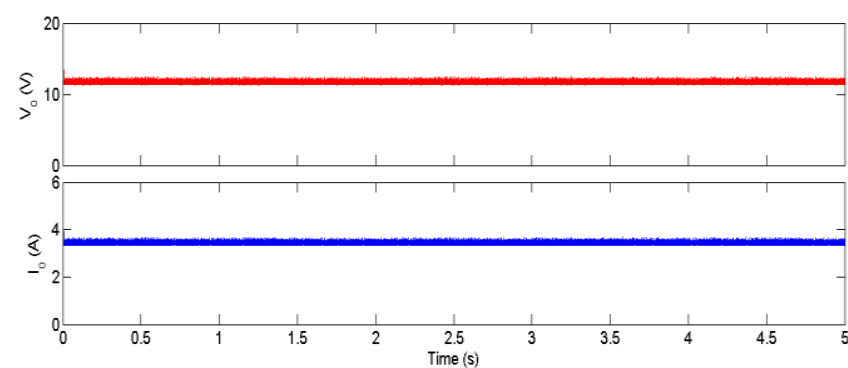

Fig -11: Simultaneous operation: Output voltage and current

It can be seen that the output voltage settles at $12 \mathrm{~V}$. Figure 12 shows the voltage stresses across the switches $M_{1}$ and $\mathbf{M}_{2}$. Maximum stresses across $\mathbf{M}_{1}$ and $\mathbf{M}_{2}$ are obtained as 27 $\mathrm{V}$ and $35 \mathrm{~V}$. Output voltage ripple is found as $0.8 \mathrm{~V}$, i.e., $6.5 \%$ of the average output voltage. The output voltage ripple is shown in figure 13.

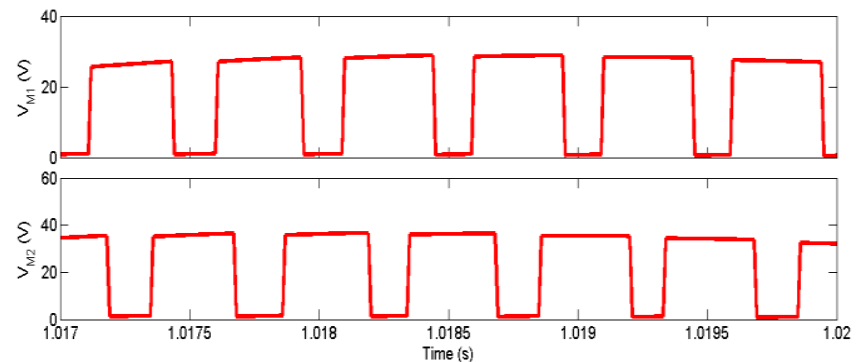

Fig -12: Simultaneous operation: Voltage stresses across $M_{1}$ and $\mathrm{M}_{2}$

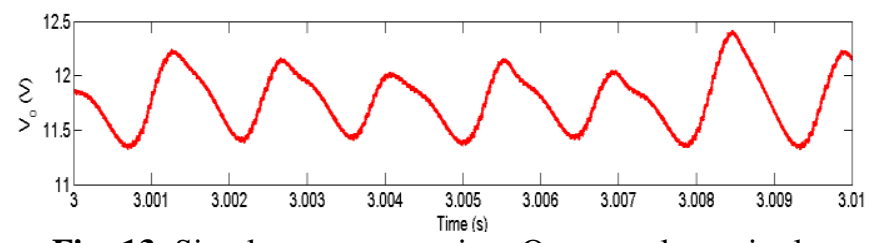

Fig -13: Simultaneous operation: Output voltage ripple

\subsection{Individual Operation - Only Solar Array Input}

Input terminal 1 is connected to a $10 \mathrm{~V} \mathrm{DC}$ and the input terminal 2 is open-circuited. Figure 14 shows the input voltage and current from the source $\mathrm{V}_{1}$. Output voltage and current obtained is plotted in figure 15. Output voltage is found as $12 \mathrm{~V}$.

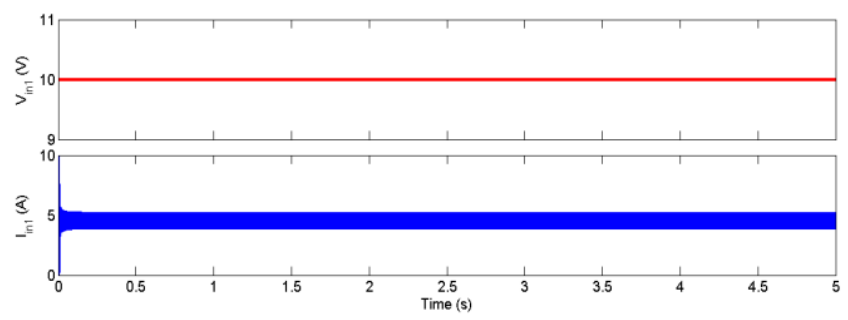

Fig -14: Individual operation (only $\mathrm{V}_{1}$ ): Input 1 voltage \& current

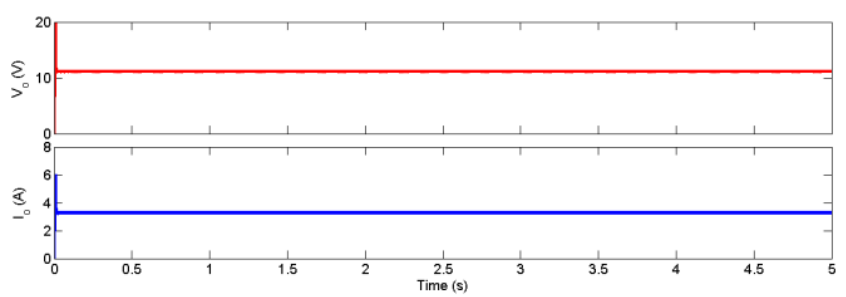

Fig -15: Individual operation (only $\mathrm{V}_{1}$ ): Output voltage and current

Figure 16 shows the voltage stress across $M_{1}$ and its maximum value is obtained as $22 \mathrm{~V}$. Output voltage ripple is shown in figure 17 and it's found to be $0.004 \mathrm{~V}$, i.e., $0.03 \%$ of average output voltage.

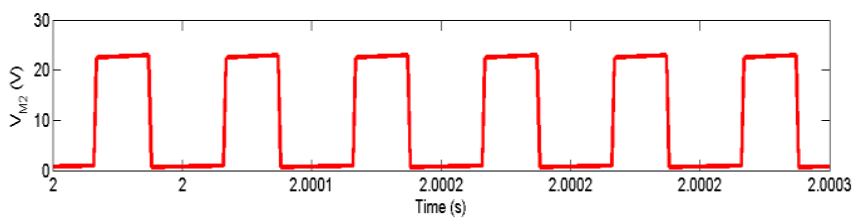

Fig -16: Individual operation (only $\mathrm{V}_{1}$ ): Voltage stress across $\mathrm{M}_{1}$

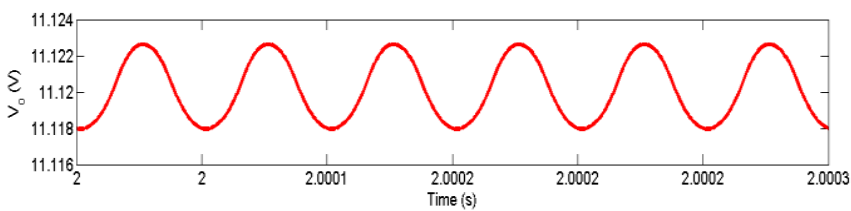

Fig -17: Individual operation (only $\mathrm{V}_{1}$ ): Output voltage ripple

\subsection{Individual Operation - Only Fuel Cell Input}

Input terminal 2 is connected to a $14 \mathrm{~V} \mathrm{DC}$ and the input terminal 1 is open-circuited. Figure 18 shows the input voltage and current from the source $\mathrm{V}_{2}$. Output voltage and current obtained is plotted in figure 19. Output voltage is found as $12 \mathrm{~V}$. 


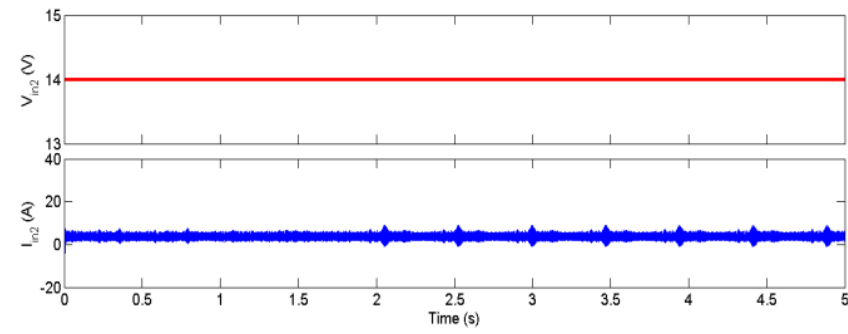

Fig -18: Individual operation (only $\mathrm{V}_{2}$ ): Input 2 voltage \& current

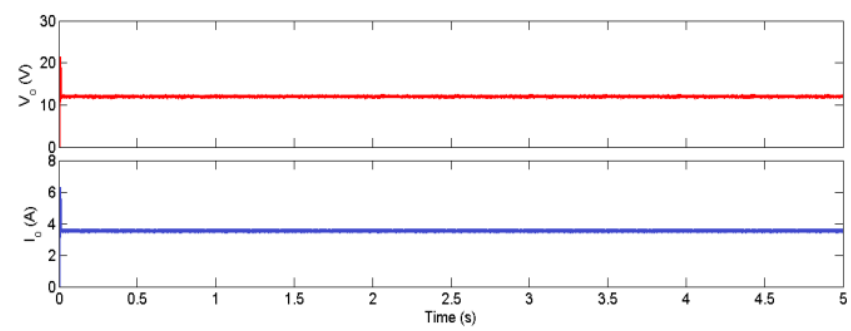

Fig -19: Individual operation (only $\mathrm{V}_{2}$ ): Output voltage and current

Figure 20 shows the voltage stress across $\mathrm{M}_{2}$ and its maximum value is obtained as $28 \mathrm{~V}$. Output voltage ripple is shown in figure 21 and it's found to be $0.005 \mathrm{~V}$, i.e., $0.04 \%$ of average output voltage.

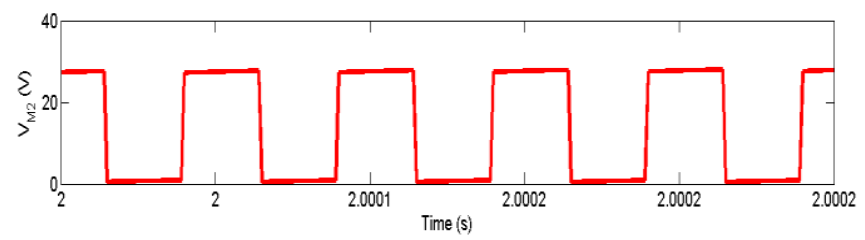

Fig -20: Individual operation (only $\mathrm{V}_{2}$ ): Voltage stress across $\mathrm{M}_{2}$

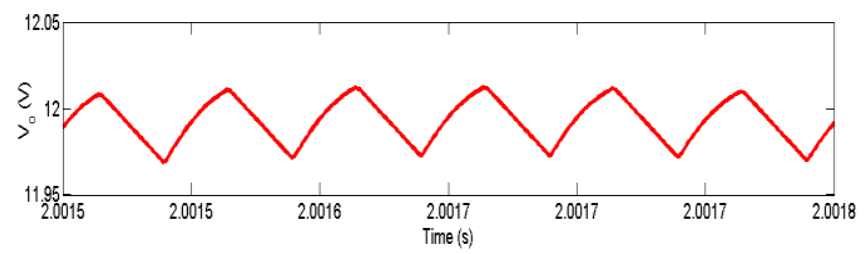

Fig -21: Individual operation (only $\mathrm{V}_{2}$ ): Output voltage ripple

\section{EXPERIMENTAL SETUP \& RESULTS}

The basic experimental set up is shown in figure 22. The power circuit as well as control circuit is powered from lab power supply. dsPIC30F2010 is the controller employed for the converter control. A12 V DC motor is used as a servo motor load for the converter. The servo motor is controlled by another dsPIC30F2010. Fuzzy logic control is implemented in both the controllers

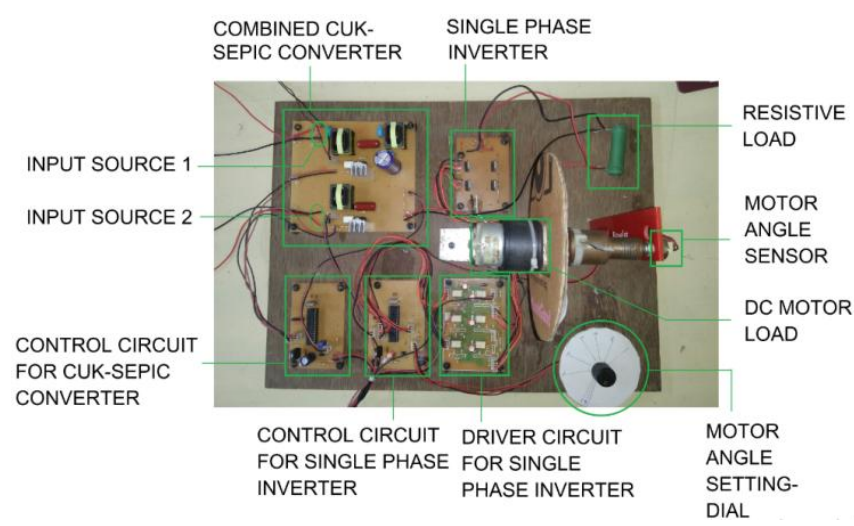

Fig -22: Experimental setup

\subsection{Experimental Parameters}

Table -2: Experimental setup Parameters

\begin{tabular}{|c|c|c|}
\hline \multicolumn{2}{|c|}{ Parameters/Components } & Values \\
\hline \multicolumn{2}{|c|}{ Input Voltage $1\left(\mathrm{~V}_{1}\right)$} & $10 \mathrm{~V}( \pm 2 \mathrm{~V})$ \\
\hline \multicolumn{2}{|c|}{ Input Voltage $2\left(\mathrm{~V}_{2}\right)$} & $14 \mathrm{~V}( \pm 4 \mathrm{~V})$ \\
\hline \multicolumn{2}{|c|}{ Output Voltage $\left(\mathrm{V}_{\mathrm{o}}\right)$} & $12 \mathrm{~V}$ \\
\hline \multicolumn{2}{|c|}{ Power Output $\left(\mathrm{P}_{\mathrm{o}}\right)$} & $12 \mathrm{~W}$ \\
\hline \multirow{3}{*}{ Inductors } & $\mathrm{L}_{1}$ & $750 \mu \mathrm{H}$ \\
\hline & $\mathrm{L}_{2}$ & $140 \mu \mathrm{H}$ \\
\hline & $\mathrm{L}_{3}$ & $1200 \mu \mathrm{H}$ \\
\hline \multirow{3}{*}{ Capacitors } & $\mathrm{C}_{1}$ & $1 \mu \mathrm{F}$ \\
\hline & $\mathrm{C}_{2}$ & $4700 \mu \mathrm{F}$ \\
\hline & $\mathrm{C}_{3}$ & $1 \mu \mathrm{F}$ \\
\hline \multicolumn{2}{|c|}{ Switching Frequency $\left(\mathrm{F}_{\mathrm{s}}\right)$} & $20 \mathrm{kHz}$ \\
\hline \multicolumn{2}{|l|}{ MOSFETs } & $\begin{array}{l}\text { P60NF06, } \\
\text { P55NF06 }\end{array}$ \\
\hline \multicolumn{2}{|l|}{ Diodes } & HF06, IN5408 \\
\hline \multicolumn{2}{|l|}{ Motor Load } & $\begin{array}{l}12 \mathrm{~V} \quad \mathrm{DC} \\
\text { Motor }\end{array}$ \\
\hline \multicolumn{2}{|l|}{ Controller } & dsPIC30F2010 \\
\hline \multicolumn{2}{|l|}{ Gate Driver } & $\begin{array}{l}\text { TLP250, } \\
\text { TLP350 }\end{array}$ \\
\hline
\end{tabular}

\subsection{Simultaneous Operation}

The input terminal 1 of the converter is connected to a $10 \mathrm{~V}$ DC supply and input terminal 2 is connected to a $14 \mathrm{~V} \mathrm{DC}$ supply. Pulses are generated and are supplied to switches $\mathrm{M}_{1}$ and $\mathrm{M}_{2}$. It can be seen that they are of equal width and are $180^{\circ}$ phase shifted. These pulses are plotted in figure 23. Figure 24 shows the output voltage waveform obtained during simultaneous operation. It can be seen that the output voltage settles at $12 \mathrm{~V}$. 


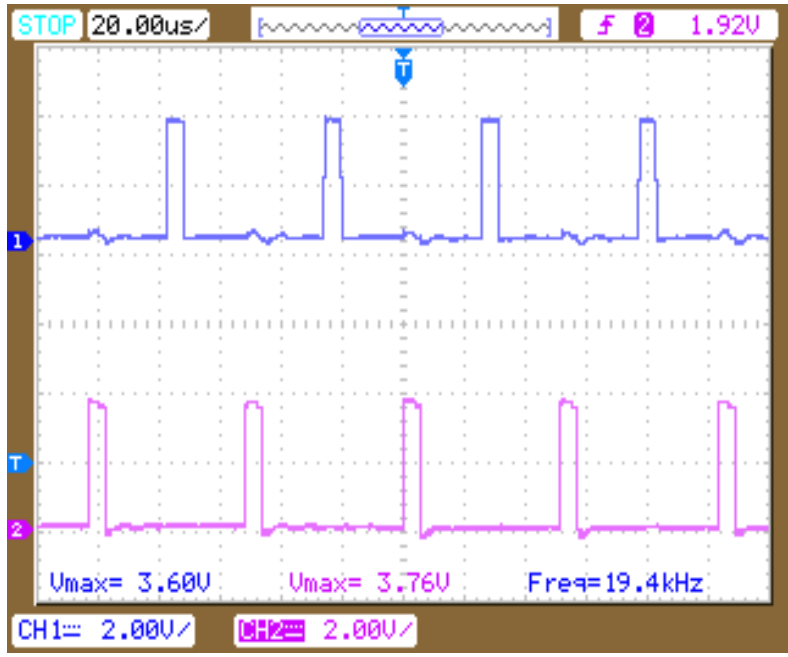

Fig -23: Simultaneous operation: Pulses to $\mathrm{M}_{1}$ and $\mathrm{M}_{2}$

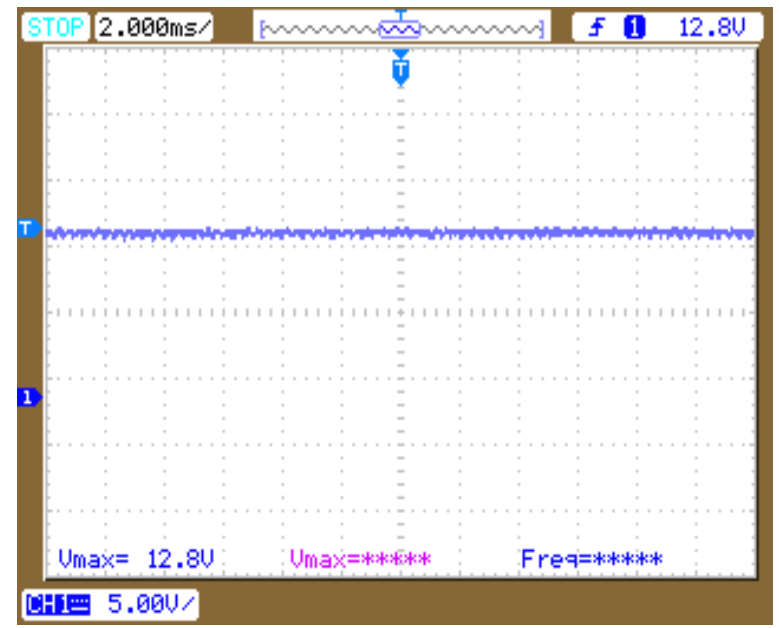

Fig -24: Simultaneous operation: Output voltage

\subsection{Individual Operation - Only Solar Array Input}

The input terminal 1 of the converter is connected to a $10 \mathrm{~V}$ DC supply and input terminal 2 is open-circuited. Only the Cuk converter section operates. The pulse to $M_{1}$ is plotted in figure 25. Figure 26 shows the input voltage $V_{1}$ and output voltage waveform obtained during the operation. It can be seen that the output voltage settles at $12 \mathrm{~V}$.

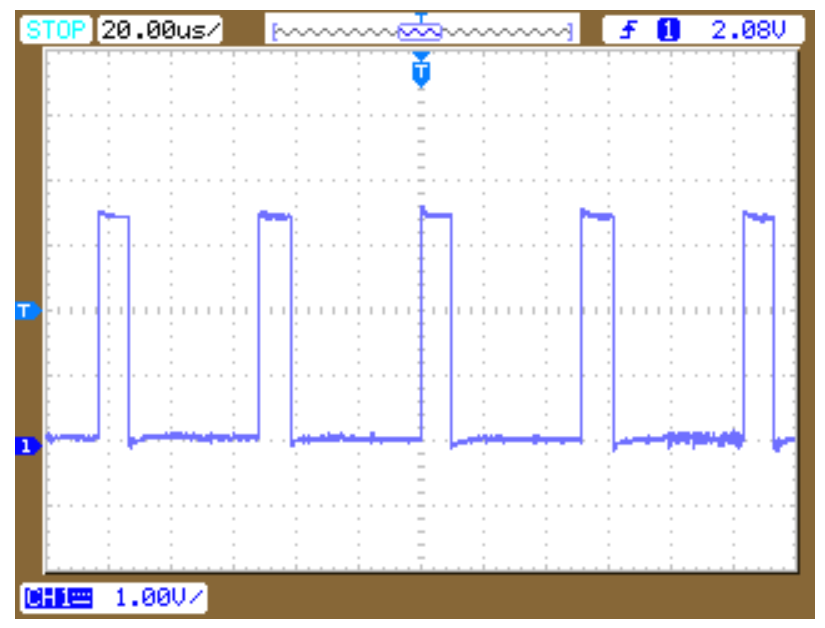

Fig -25: Individual operation (only $\mathrm{V}_{1}$ ): Pulse to $\mathrm{M}_{1}$

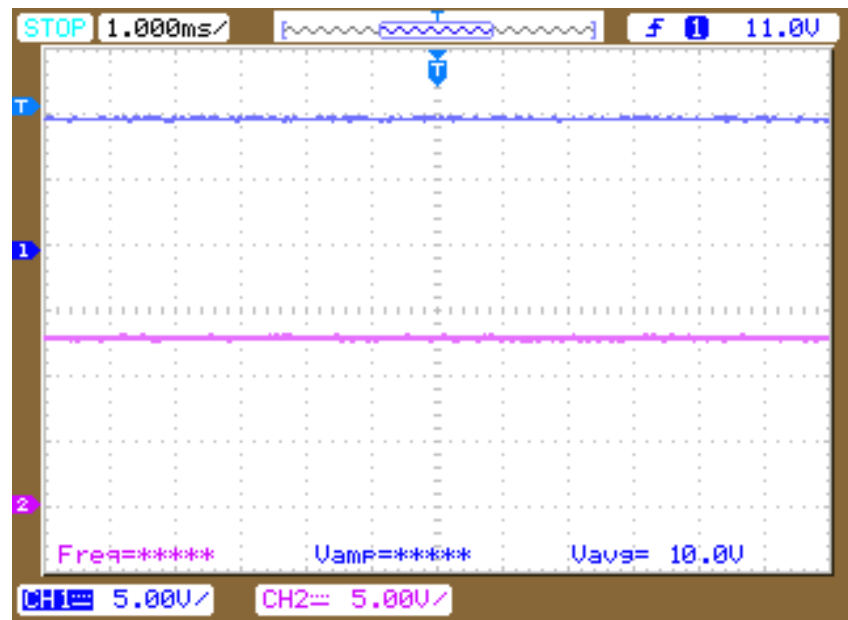

Fig -26: Individual operation (only $\mathrm{V}_{1}$ ): Output voltage

\subsection{Individual Operation - Only Fuel Cell Input}

The input terminal 1 of the converter is open-circuited and input terminal 2 is connected to a 14 V DC supply. Only the SEPIC converter section operates. The pulse to $\mathrm{M}_{2}$ is plotted in figure 27. Figure 28 shows the input voltage $V_{2}$ and output voltage waveform obtained during the operation. It can be seen that the output voltage settles at $12 \mathrm{~V}$.

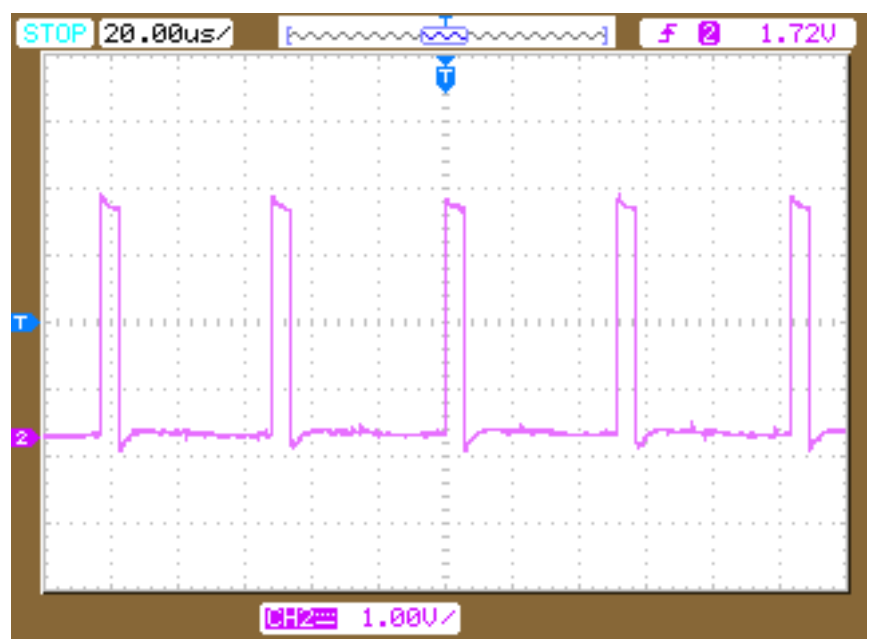

Fig -27: Individual operation (only $\mathrm{V}_{2}$ ) Pulse to $\mathrm{M}_{2}$

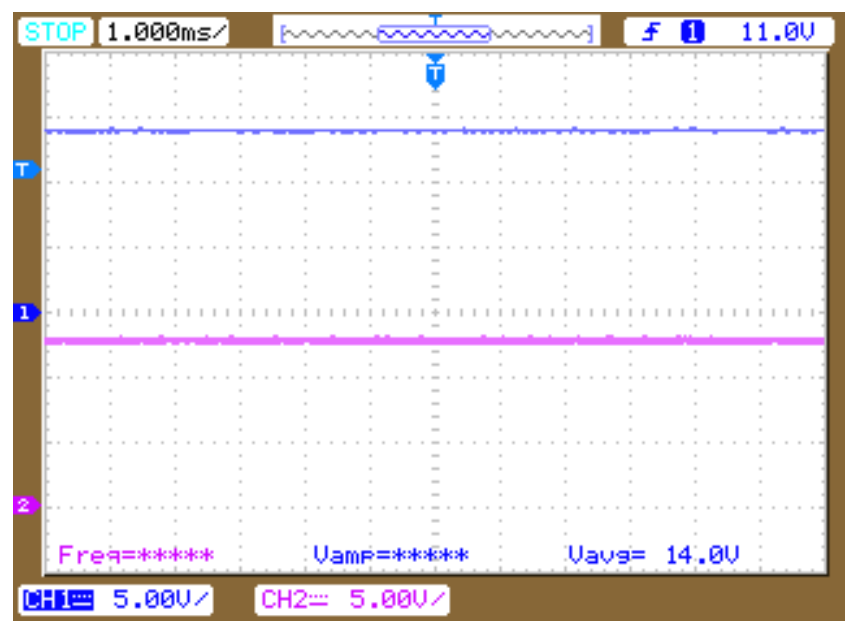

Fig -26: Individual operation (only $\mathrm{V}_{2}$ ) : Output voltage 


\subsection{Experimental Results: Servo Motor Load}

With the constant DC output voltage obtained from the converter, the DC motor load is driven as a servo motor using a two leg inverter. The rotor position of the motor can be set to any required position within a range of $270^{\circ}$. The control for this motor is also implemented using fuzzy logic. The control circuit determines whether the rotor has to rotate clockwise or anti-clockwise depending on the required rotor position and the current rotor position. The real-time error (required value - actual value) is calculated and the motor rotates at a speed proportional to it and the speed reduces to zero when the required position is reached.

\section{CONCLUSION}

A multi-input Cuk-SEPIC DC-DC converter for hybrid solar array-fuel cell systems has been presented. It is a solution for the inconsistency problems associated with renew- able energy source. It can enhance the efficiency and reliability of the power system through hybridization. The circuit has the advantage of individual step up/step down of the sources and thus enabling individual and simultaneous operation. Since it is the combination of two basic DC-DC converters, there is a reduction in the passive component count. This system has lower operating cost and finds applications in remote area power generation, constant speed and variable speed energy conversion systems and rural electrification. Simulation results have been presented using MATLAB/Simulink to verify the features of the converter. A prototype was designed and manufactured an the results were verified. The control of the setup was established using fuzzy logic. A DC motor was connected as the load for the converter and it is run as a servo motor. The motor angle control is also established by fuzzy logic. Fuzzy logic control provided a better settling time and a reduction in the ripples in the output voltage waveform. This was tested and verified using the simulation models.

\section{REFERENCES}

[1] S. K. Kim, J. H. Jeon, C. H. Cho, J. B. Ahn and S. H. Kwon, "Dynamic Modeling and Control of a Grid Connected Hybrid Generation System with Versatile Power Transfer', IEEE Transactions on Industrial Electronics, vol.55, pp.1677- 1688, 2008.

[2] D. Das, R. Esmaili, L. Xu and D. Nichols, "An Optimal Design of a Grid Connected Hybrid Wind/Photovoltaic/Fuel Cell System for Distributed Energy Production", Proc. IEEE Industrial Electronics Conference, pp.2499-2504, 2005.

[3] N. A. Ahmed, M. Miyatake and A. K. Al-Othman, "Power fluctuations suppression of standalone hybrid generation combining solar photovoltaic/wind turbine and fuel cell systems', Proc. of Energy Conversion and Management', vol.49, pp. 2711-2719, 2008.

[4] S. Jain and V. Agarwal, “An Integrated Hybrid Power Supply for Distributed Generation Applications fed by Non conventional Energy Sources', IEEE Transactions on Energy Conversion, vol.23, 2008.
[5] Y. M. Chen, Y. C. Liu, S. C. Hung and C. S. Cheng, "Multi-Input Inverter for Grid Connected Hybrid PV/Wind Power System', IEEE Transactions on Power Electronics, vol.22, 2007.

[6] F. Akar, Y. Tavlasoglu, and E. Ugur, "Bidirectional Non-Isolated Multi-Input DC- DC Converter for Hybrid Energy Storage Systems in Electric Vehicles", IEEE Transactions on Vehicular Technology, 2015.

[7] A. A. Anu and R. Divya, "Multiple Input DC-DC Converters for Solar Cell Power Supply System and Its Maximum Power Point Tracker', IEEE Transactions on Power Electronics, 2013.

[8] A. E. Khateb, N. A. Rahim and J. Selvaraj, "Fuzzy Logic Controller Based SEPIC Converter for Maximum Power Point Tracking', IEEE Transactions on Industry Applications, 2014.

[9] B. J. Justin and S. R. Reddy, "Fuzzy Controlled SEPIC Based Micro Wind Energy Conversion System with Reduced Ripple and Improved Dynamic Response", Journal of Electrical Engineering, 2015. 